\title{
The Implementation Of Character Education In Indonesian Language Learning In Class VIII UPT SPF SMPN 53 Makassar
}

\author{
Muhammad Akhir \\ Universitas Muhammadiyah Makassar \\ E-mail:m.akhir@unismuh.ac.id
}

Received: 2 November 2021; Revised: 25 November 2021; Accepted: 27 November 2021

\begin{abstract}
This study describes the implementation of character education in Indonesian language learning, including planning, implementation, and assessment. This research is descriptive research with a qualitative approach. The subjects of this study were Indonesian language teachers at UPT SPF SMPN 53 Makassar. Data were obtained through interviews, questionnaires, observations, and documentation analysis. The credibility test of the data used in this study is the persistence of observations, and then conclusions are obtained. The results obtained in this study are character education in Indonesian language learning at UPT SPF SMPN 53 Makassar has been implemented both in planning, implementation, and assessment of learning but not all of it has been implemented because it is still in the covid-19 pandemic. At the learning planning stage, the Indonesian language teacher has included character values that will be implemented in learning in the syllabus and lesson plans. The implementation of Indonesian language learning at UPT SPF SMPN 53 Makassar has been quite implemented through online learning via WhatsApp. Assessment of Indonesian language learning includes effective assessment.
\end{abstract}

Keywords: Language Learning; Character Education; Indonesian;

\section{Introduction}

Facing various challenges in the national education system of the 21 st century, explicitly preparing quality and competitive future for the country. One of the most critical things in the 21 st century is strengthening character education (Iswan \& Bahar, 2018) and facing the era of the industrial revolution 4.0 (Silfia, 2018). The development of the nation's character is the most crucial focal point not to be separated from national development (Akhir, 2017).

Law No. 17 of 2007 concerning 2 National Long-Term Development Plans for 2005-2025 concerning the development of the nation's character in national policies are formulated to implement the mandate. Of the eight missions that realize the vision of National development, the first mission is developing the nation's character (Bappenas, 2005).

Ministry of National Education (2010) The achievement of national character development is marked by the formation of a nation that is strong, virtuous, competitive, tolerant, cooperative, energetic, ethical, educated, patriotic, and has science and technology insight Pancasila, filled with faith and piety for the One God. Almighty. Building national character is contained in the National policy of Permendikbud No. 54 of 2013 regarding the competence of graduates must have attitudes, skills, and knowledge. The attitude aspect is an aspect related to the character of students.

Behavior that reflects the actions of people with noble character, faith, knowledge, trustworthiness and responsibility for affective interactions with relationships and the social and natural environment within the scope of their existence. Government Regulation No. 19 of 2005 concerning National Education Standards Article 7 No. 2, is the implementation of personality or character education which is regulated in the implementation of education at 
all levels through content or activities of noble character, religion, language, citizenship, physical education, and cultural arts. The Minister of National Education explains that one way to develop personality or character is through language, such as developing Indonesian language teaching materials.

In junior high school, Indonesian language lessons are functionally aimed at making Indonesian a professional and scientific language. According to the Decree of the Minister of National Education of the Republic of Indonesia Number 232/U/2000, there are guidelines for preparing the syllabus for three universities and the core syllabus for higher education and achievement assessment. Learn for students.

In junior high school, the implementation of Indonesian language education is still not improving. The achievement of language learners is closely related to willpower. Learning a language is not just memorizing, creating, reading, or listening, but the importance is more than the hope of reaching the future.

At the same time, Indonesian language teachers hope that every student will achieve graduate competence in terms of knowledge, skills, especially attitudes or character. The achievement of these students depends on the ability of professional Indonesian teachers, the teacher's appreciation of students to create student behavior with character.

There are many irregularities committed by generations of the Indonesian nation, from school to university levels. Cases of irregularities that often occur in students at school include cheating during exams or tests, delinquency, brawls, violence, disrespectful murder, irresponsibility, dishonesty, distrust, promiscuity, sucking glue, motorcycle gangs, bullying, using drugs. Drugs and drinking (Suardi et al., 2020) (Kanji et al., 2019b), truancy, smoking, undisciplined (Suardi et al., 2018). Cases of irregularities that often occur in college students such as conflicts, anarchist demonstrations, free sex, drug use, cheating, smoking, fights between students (Suardi \& Syarifuddin, 2018). One of the contributing factors is the student's internal self, namely the character of the student or student who still needs to be grown and developed (Suardi et al., 2018).

The number of cases of deviant behavior shows that in the school environment, character values must be improved. It is hoped that the instilled character values can build the attitude of students who have good character in school, family, and community life.

The researcher's observations of student behavior during the learning process related to negative aspects of student attitudes, such as not submitting assignments on time, being late for class, making noise during learning, cheating and not reading the worksheet instructions correctly during learning. Their activities are beyond practical instruction. If this situation is not addressed immediately, serious consequences will arise because of character deviations. However, they can have implications for the school system and negatively impact learning inputs, processes, and outputs (Suardi et al., 2018). In addition, it can also have an impact on (a) erosion of character, erosion of good behavior and erosion of positive behavior, (b) unity and solidarity (low high frequency of brawls and fights and law violations), (c) many children who are only successful in the cognitive field. So that (d) the country's competitiveness is reduced.

Overcoming this requires character education (Suardi et al., 2018). The aim is to develop students' character through all levels of education, both in school education and in higher education.

Character education in schools can be done through the learning process in every subject taught by the teacher (Kanji et al., 2019b) (Suardi et al., 2019) (Kanji et al., 2019a), more specifically character education in Indonesian language learning (Sulistiyowati, 2013) (Akhir, 2017) (Akhir, 2018) (Akhir, 2016a) (Akhir, 2016b). Characters that can be developed such as disciplined character and responsibility character (Akhir, 2017) (Akhir, 2016a), honest character, responsible character, confident character, polite character, hard work character, creative character, independent character, conscientious character and careful character ( Akhir, 2018). In Indonesian language lessons in schools, the concept of character education is a unity in every aspect of learning, starting from planning and implementing to evaluating. So the researcher wants to describe the factors regarding planning, implementation, and assessment in Indonesian language learning with the research title "implementation of character education in Indonesian language learning in class VIII UPT SPF SMPN 53 Makassar." 


\section{Materials and Methods}

The type used in this research was descriptive qualitative. Anggito and Johan (2018) reveal that qualitative research collected data in the natural environment to interpret phenomena that prevented observers from being the primary tool, deliberately selected data sources, triangular (combined) collection techniques, and data analysis with an inductive/ qualitative nature. And the results of qualitative research prioritized meaning rather than generalization. This study described the implementation of character education in Indonesian language learning for students in class VIII.A UPT SPF SMPN 53 Makassar. This research covered the mechanism of planning, implementing, and assessing Indonesian language learning in class VIII.A UPT SPF SMPN 53 Makassar.

\section{Results and Discussion}

The research results are related to the planning, implementation, assessment, and implementation of character education in Indonesian language learning at UPT SPF SMPN 53 Makassar, which is network-based (online) via online media via WhatsApp to the Covid-19 pandemic. Indonesian language learning through this online mode has been carried out during the COVID-19 pandemic, including at UPT SPF SMPN 53 Makassar.

\section{Character Education Planning in Indonesian Language Learning}

Character education is the process of instilling the values of everyday life in the learning process for students. Character education in Indonesian language learning at UPT SPF SMPN 53 Makassar begins after 2019. Character education in learning Indonesian at UPT SPF SMPN 53 Makassar starts from teachers teaching Indonesian language learning. Teachers have an essential role in fostering.

The teacher plans the implementation of character teaching in learning by compiling a syllabus and lesson plan. The learning implementation plan used during the COVID-19 pandemic is a sheet learning implementation plan that is always provided and updated before teaching. The teacher carries out learning according to students' interests.

The teacher uses a four-sheet learning syllabus and lesson plan with character values listed. Through the syllabus and lesson plans made before learning, the teacher has implemented character education implementation plans.

The teacher includes the character values to be achieved in the lesson plan and syllabus in the character education implementation plan. In contrast to (Azmi Nailul, 2017), character education's planning stage includes extracurricular activities, civilizing activities, and habituation.

The teacher chooses the character values to be achieved through the school's thoughts that align with the selection of character values and the school's vision and mission. Character values must be achieved by adapting methods, materials, learning media, and strategies. Planning for learning character values to be performed is in accordance with the school's vision and mission, school regulations, media, materials, learning methods, and strategies.

Learning planning using character values is the value of intelligence, the value of honesty, the value of care, the value of toughness and discipline. There are four skills in learning Indonesian: speaking skills, listening skills, reading skills, and writing skills (Akhir, 2017) (Akhir, 2016b). Of the four Indonesian language skills listed in the syllabus and syllabus, the analysis of the learning implementation plans that appear in the character values is not the same.

\section{Implementation of Character Education in Indonesian Language Learning}

The implementation of character education at UPT SPF SMPN 53 Makassar is carried out online through the WhatsApp group, namely subjects and culture. Through school culture in the implementation of character education. The performance of character education is strongly influenced by the school's cultural environment (Ruyadi, 2010), such as discipline while studying, which is carried out from 08.00 to 14.00. Implementation of character education at UPT SPF SMPN 53 Makassar. Through the example of the teacher being on time entering the classroom guided through the WhatsApp class because there has been a regular distribution of learning schedules that the teacher has known. The student organization is part of the character development of students (Melisa, 2014). 
In contrast to (Azmi Nailul, 2017), the stage of implementing character education includes implementing extracurricular activities, civilizing activities, and the implementation of habituation. Meanwhile (Saputri, 2013), the performance of character education is carried out by integrating character education values in learning. These extracurricular activities integrate character values and habituation through the creation of school culture with character.

At UPT SPF SMPN 53 Makassar, the character values have been completely updated in the implementation of Indonesian language learning. Learning materials that always contain character values. Learning activities in accordance with the material being taught include character values used in learning media. Learning activities are based on lesson plans that are conditioned with class situations. At UPT SPF SMP Negeri 53, Makassar in learning includes listening, speaking, reading, and writing skills (Akhir, 2017) (Akhir, 2016b).

\section{Assessment of Character Education in Indonesian Language Learning}

The teacher carries out an evaluation or assessment of character education from questions and behavior, all of which are to prove character values and questions that are still related to learning materials in students' abilities. Evaluation of character assessment is also carried out through research. There are no students who pass the learning material if the character education does not pass. Graduation of character education affects Indonesian language subjects.

Teachers include practical assessments in the lesson plans, which are always communicated to the homeroom teacher, then communicate to parents the results of the character education carried out. In contrast to (Kanji et al., 2019a) who evaluate character education more broadly, namely through learning input, process and output.

Planning, implementation, assessment of the implementation of character education in Indonesian language learning at UPT SPF SMPN 53 Makassar, which is network-based (online) via online media via WhatsApp, as a result of the Covid-19 pandemic has been carried out during the covid-19 pandemic.

\section{Conclusion}

The implementation of character education in Indonesian language learning at UPT SPF SMPN 53 Makassar is carried out through planning, implementation, and assessment. The activities of Indonesian language teachers at UPT SPF SMPN 53 Makassar in learning planning add the character values to be achieved in the RPP and RPP for each basic competency. At the planning stage, the teacher selects character values adapted to the methods, materials, media, strategies, and learning situations. Assessment of Indonesian language learning includes the affective assessment. Indonesian language learning consists of four competencies, namely listening skills, speaking skills, and speaking skills.

\section{Suggestion}

Future research can examine more deeply and more specifically one aspect of learning Indonesian, such as reading skills or other skills.

\section{References}

Akhir, M. (2017). PENGEMBANGAN MATERI AJAR BAHASA INDONESIA BERBASIS KARAKTER [Universitas Negeri Makassar]. In Solid State Ionics. http:// linkinghub.elsevier.com/retrieve/pii/ S0167273817305726\%0Ahttp:// dx.doi.org/10.1038/s41467-017-01772-1\% 0Ahttp://www.ing.unitn.it/ luttero/ laboratoriomateriali/ RietveldRefinements.pdf\%0Ahttp:// www.intechopen.com/books/spectroscopicanalyses-developme

Akhir, M. (2018). INTEGRASI PENDIDIKAN KARAKTER DALAM MENINGKATKAN KETERAMPILAN MENULIS MAHASISWA DI PERGURUAN TINGGI. Universitas Muhammadiyah Jakarta, 1(1), 523-536. https://jurnal.umj.ac.id/index.php/ SNP/article/view/2795

Akhir, M. (2016a). PENGEMBANGAN MATERI AJAR BAHASA INDONESIA BERBASIS KARAKTER PADA MAHASISWA UNIVERSITAS MUHAMMADIYAH MAKASSAR. International Seminar on Quality and Affordable Education | IS$Q A E$, 663-674. www.uty.ac.id

Alphansyah. (2020). Desain Pembelajaran Bahasa Indonesia Berbasis Karakter. Jawa barat: GuePedia.

Akhir, Muhammad. (2017). Pengembangan Materi Ajar Bahasa Indonesia Berbasis 
Karakter. Disetasi tidak diterbitkan. Makassar: Universitas Negeri Makassar.

Azmi Nailul. (2017). Manajemen Pendidikan Karakter Siswa Man 1 Brebes dan MAN 2 Brebes [INSTITUT AGAMA ISLAM NEGERI PURWOKERTO]. http:// repository.iainpurwokerto.ac.id/id/ eprint $/ 2993$

Bappenas. (2005). Visi dan Arah Pembangunan Jangka Panjang (PJP) tahun 2005-2025. In Badan Perencanaan Pembangunan Nasional. Kantor Menteri Negera Perencanaan Pembenagunan Nasional/Badan Perencanaan Pembangunan Nasional. https:// www.bappenas.go.id/files/1814/2057/0437/ RPJP_2005-2025.pdf

Iswan, I., \& Bahar, H. (2018). PENGUATAN PENDIDIKAN KARAKTER PERSPEKTIF ISLAM DALAM ERA MILLENIAL IR. 4.0. Prosiding Seminar Nasional Pendidikan, 1(1), 21-42. https://jurnal.umj.ac.id/ index.php/SNP/article/view/2756

Hilaliyah, Tatu. (2017). Tes Keterampilan Berbahasa pada Siswa. Jurnal: Membaca Bahasa \& Sastra indonesia. (Online), Vol.2, No. 1. (Https://jurnal.untirta.ac.id,diakses 3 Februari 2021).

Kanji, H., Nursalam, N., Nawir, M., \& Suardi, S. (2019a). Evaluasi Integrasi Pendidikan Karakter dalam Pembelajaran Ilmu Pengetahuan Sosial di Sekolah Dasar. JED (Jurnal Etika Demokrasi), 4(2), 56-63. https:// doi.org/10.26618/jed.v4i2.2386

Kanji, H., Nursalam, Nawir, M., \& Suardi. (2019b). Model Integrasi Pendidikan Karakter dalam Pembelajaran Ilmu Pengetahun Sosial di Sekolah Dasar. Jurnal Pendidikan Dasar Perkhasa , 5(2), 104-115. https:// doi.org/10.31932/jpdp.v5i2.458

Melisa, O. D. (2014). Model Pendidikan Karakter di Islamic Full Day School (Studi Deskriptif pada SD Cendekia Leadership School, Bandung). TARBAWY: Indonesian Journal of Islamic, 1(2), 132. https://ejournal.upi.edu/ index.php/tarbawy/article/view/3769

Mustoip Sofyan, Muhammad Japar \& Zulela. 2018. Implementasi Pendidikan Karakter. Surabaya: CV. Jakad Media Publish.Ruyadi, Y. (2010). kearifan budaya lokal: penelitian terhadap masyarakat adat Kampung Benda Kerep, Cirebon, Provinsi Jawa Barat untuk pengembangan pendidikan karakter.... File.Upi.Edu, 576-594. http://file.upi.edu/ Direktori/PROCEEDING/UPI-UPSI/2010/
Book_3/

MOD-

EL_PENDIDIKAN_KARAKTER BER BASIS_KEARIFAN̄_BUDAYA_LOKA $\mathrm{L}$

(Penelitian_terhadap_Masyarakat_Adat_ Kam-

pung_Benda_Kerep_Cirebon_Provinsi_J awa Barat untuk Pengembangan Pendi dikan Karakter di Sekolah).PDF

Saputri, M. (2013). PELAKSANAAN PENDIDIKAN KARAKTER DI SD KASIHAN KABUPATEN BANTUL. Hanata Widya, 2(6), 1-15. http:// journal.student.uny.ac.id/ojs/ojs/ index.php/fipmp/article/view/624

Silfia, M. (2018). Penguatan Pendidikan Karakter dalam Menghadapi Era Revolusi Industri 4 . 0. Prosiding Seminar Nasional FIS, 2, 642-645.

Suardi, Agustang, A., \& Sahabuddin, J. (2020). MODEL KOLABORASI SOSIAL PENDIDIKAN KARAKTER DI SEKOLAH SWASTA KECAMATAN BISSAPPU KABUPATEN BANTAENG. PROSIDING SEMINAR DAN DISKUSI PENDIDIKAN DASAR, 1-11. http://journal.unj.ac.id/unj/index.php/ psdpd/article/view/17769

Suardi, S., Herdiansyah, H., Ramlan, H., \& Mutiara, I. A. (2019). Implementasi Pendidikan Karakter Melalui Mata Pelajaran Pendidikan Kewarganegaraan di SMA Jaya Negara Makassar. JED (Jurnal Etika Demokrasi), 4(1), 22-29. https:// doi.org/10.26618/jed.v4i1.1983

Suardi, S., Megawati, M., \& Kanji, H. (2018). Pendidikan Karakter di Sekolah (Studi Penyimpangan Siswa di Mts Muhammadiyah Tallo). JED (Jurnal Etika Demokrasi), 3(1), 75-84. https:// doi.org/10.26618/jed.v3i1.1979

Suardi, \& Syarifuddin. (2018). Penerapan Model Pembelajaran Saintifik Approacd Berbasis Media Pembelajaran Kearifan Lokal pada Mata Kuliah Dasar-Dasar Sosiologi dalam Membangun Karakter dan Meningkatkan Hasil Belajar Mahasiswa Pendidikan Sosiologi Universitas Muhammadiyah Makassar. JED (Jurnal Etika Demokrasi), 3(2), 75-85. https:// doi.org/10.26618/jed.v3i2.1627

Sulistiyowati, E. (2013). Pendidikan Karakter Dalam Pembelajaran Bahasa Indonesia. 
Edukasia: Jurnal Penelitian Pendidikan Islam, 8(2), 63-68. https://doi.org/10.21043/ edukasia.v8i2.756

Syanurdin, S. (2020). Pembelajaran Bahasa Indonesia Berbasis Digital dalam Membina Karakter Siswa. Seminar Nasional Pendidikan Bahasa Dan Sastra, November 2019, 44 -51. https://ejournal.unib.ac.id/index.php/ semiba/article/view/13410

Rosad, Ali Miftakhul. (2019). Implementasi Pendidikan Karakter Melalui Pembelajaran di Lingkungan Sekolah. Jurnal Keilmuan Menajemen Pendidikan. (Online), Vol. 5, No. 2. Sarkadi. 2020. Tahap Penilaian Pembelajaran Bersadarkan Kurikulum 2013. Surabaya: CV Jakad Media Publishing.

Sholichah, Aas Siti. (2018). Teori-teori Pendidikan dalam Al-Qur'an. Jurnal Pendidikan Islam. (Online), Vol. 07, No. 1. (www.Jurnal.staialhidayahbogor.ac.id diakses 1 Februari 2020 